\title{
ASSESSING INDONESIA-CHILE BILATERAL TRADE OPPORTUNITIES: A REVEALED COMPARATIVE ADVANTAGE APPROACH
}

\author{
Sulthon Sjahril Sabaruddin \\ Faculty of Economics \\ Universitas 17 Agustus 1945 Jakarta \\ e-mail: ssabaruddin@yahoo.com \\ Hartanti Nugrahaningsih \\ Faculty of Economics \\ Universitas 17 Agustus 1945 Jakarta
}

\begin{abstract}
This paper analyzes the Indonesia-Chile bilateral trade opportunities based on their respective export competitiveness uses the Revealed Comparative Advantage Index for 2012. It finds that in general Indonesian exports to Chile are based on its comparative advantage, but the current exports still do not reflect its potential as most of the top ten Indonesian commodities with the strongest comparative advantage still do not able to penetrate the Chilean market. Meanwhile, the majority of the top-ten Chilean exports to Indonesia are based on its comparative advantage. Thus,both nations can still enhance bilateral trade relations particularly concerning with boosting trade relations based on their comparative advantage.
\end{abstract}

Keywords: Comparative Advantage, Export Competitiveness, Bilateral Trade

JEL classification numbers: F14, F15, F17

DOI:http://dx.doi.org/10.20885/ejem.vol5.iss1.art4

\begin{abstract}
Abstrak
Makalah ini menganalisis peluang perdagangan bilateral Indonesia-Chile berdasarkan daya saing ekspor masing-masing negara menggunakan index Revealed Comparative Advantage untuk 2012. Paper ini menemukan bahwa, secara umum, ekspor Indonesia ke Chile didasarkan pada keunggulan komparatif, tetapi ekspor saat ini masih belum mencerminkan semua potensi ekspornya karena kebanyakan dari sepuluh komoditas Indonesia dengan keunggulan komparatif terkuat masih belum mampu menembus pasar Chili. Sementara itu, sebagian besar dari sepuluh-besar ekspor Chili ke Indonesia telah didasarkan pada keunggulan komparatif. Dengan demikian, kedua negara masih bisa meningkatkan hubungan perdagangan bilateral terutama terkait dengan upaya perdagangan berdasarkan keunggulan komparatif masing-masing negara.
\end{abstract}

Keywords: Keunggulan komparatif, daya saing ekspor, perdagangan bilateral JEL classification numbers: F14, F15, F17

\section{INTRODUCTION}

Diplomatic bilateral relations between Indonesia and Chile have started since 1964 and over the years, the bilateral relations between both countries have been generally positive, good and cordial. One of the pri- orities in building a diplomatic bilateral relations with Chile is to increase bilateral economic cooperation and Indonesia considered Latin American and Caribbean regions (including Chile) as one of the alternative markets. The Ministry of Foreign Affairs for the Republic of Indonesia 
(MoFA) classified Latin American and Caribbean regions, Central and Eastern Europe, Central Asia and Africa as alternative markets. Alternative markets are nontraditional markets and are considered to be an opportunity for Indonesia to diversify its exports and world markets in order to help boost the Indonesian economy.

Although diplomatic bilateral relations have began since 1964, however it was in the late 1970s that both countries started to develop bilateral trade relations and particularly since the mid 1990s, IndonesiaChile bilateral trade relations showed a significant improvement. In 1993, the total value of trade between the two countries reached US $\$ 98.7$ million and rose sharply to US\$272.3 million in 1997. However, the 1997/98 Asian economic crisis and the world economic crisis have caused the bilateral trade relations to decrease in the late 1990s and early 2000s. The Asian economic crisis did not only caused the Indonesian economy and many East Asian countries to collapse, but also did impact on many other countries around the globe. Chile as a small open economy, although successfully achieved impressive economic growth rates in early and mid 1990s, but in 1998 Chile also experienced a moderate economic recession due to the Asian economic crisis that resulted in lower export earnings for Chile. The economic downturn in both countries during the late 1990s and early 2000s has led to a lower bilateral trade relationships. To see some issues regarding the Chilean exports, please refer to Alvarez and Fuentes (2003) and Aisen et al. (2011).

The bilateral trade relations started to recover since 2004 from a total bilateral trade value of US\$201.2 million and in 2011 reached to an unprecedented level of US\$586.3 million but however the following year declined relative significantly to US\$382 million. Total trade between Indonesia and Chile during the last 5 years (2008-2012) showed a positive trend rising with an average of 4.02 percent. However, trade balance between Indonesia and Chile during the last five years (2008-2012), continued to experience a trade deficit on the Indonesian side, in which in 2011 reached its peak to -US\$158.3 million. If we trace back a decade ago, Indonesia experienced a trade deficit during the period 1997-2000 and 2004-2012, while only in the period 2001-2003 Indonesia posted a trade surplus position.

Table 1: Trade Relations between Indonesia and Chile for the Period 1997-2012 (In Million USD)

\begin{tabular}{ccccc}
\hline Year & RI Export & RI Import & Total & Trade Balance \\
\hline 1997 & 85.8 & 186.5 & 272.3 & $(100.7)$ \\
1998 & 88.9 & 109.4 & 198.3 & $(20.5)$ \\
1999 & 73.7 & 88.9 & 162.6 & $(15.3)$ \\
2000 & 84.7 & 109.0 & 193.8 & $(24.3)$ \\
2001 & 85.1 & 57.0 & 142.2 & 28.1 \\
2002 & 66.0 & 52.1 & 118.1 & 13.9 \\
2003 & 67.8 & 62.1 & 129.9 & 5.7 \\
2004 & 90.8 & 110.5 & 201.2 & $(19.7)$ \\
2005 & 113.8 & 135.6 & 249.5 & $(21.8)$ \\
2006 & 152.8 & 197.9 & 350.7 & $(45.1)$ \\
2007 & 135.4 & 202.6 & 338.1 & $(67.2)$ \\
2008 & 128.3 & 274.3 & 402.6 & $(146.0)$ \\
2009 & 166.7 & 189.3 & 356.0 & $(22.4)$ \\
2010 & 192.6 & 309.1 & 501.7 & $(116.5)$ \\
2011 & 214.0 & 372.3 & 586.3 & $(158.3)$ \\
2012 & 175.4 & 206.6 & 382.0 & $(31.2)$ \\
\hline
\end{tabular}

Source: World Integrated Trade Solution (2013) 
Indonesia's exports to Chile during the last 5 years (2008-2012) showed a rising trend with an average of 9.14 percent higher than the growth rate of the Indonesian import from Chile with an average of 1.11 percent. In 2012, Indonesian exports amounted US $\$ 175.4$ million while imports reached to an unprecedented level of US\$206.6 million. Using the HS 4 Dgits (Version 2007), Indonesian top five export commodities to Chile in 2012 are footwear with outer soles of rubber, plastics, leather or composition leather and uppers of leather (US\$30.4 million); refrigerators, freezers and other refrigerating or freezing equipment, electric or other (US\$14.6 million); coal; briquettes, avoids and similar solid fuels manufactured from coal (US\$12.5 million); other footwear with outer soles and uppers of rubber or plastics (US\$9.9 million); and footwear with outer soles of rubber, plastics, leather or composition leather and uppers of textile materials (US\$7.8 million). Meanwhile Indonesian main import commodities from Chile in 2012 are refined copper and copper alloys, unwrought (US\$72 million); iron ores and concentrates, including roasted iron pyrities (US\$29 million); chemical wood pulp, soda or sulphate, other than dissolving grades (US\$27.7 million); grapes, fresh or dried (US\$20.5 million); and fats and oils and their fractions, of fish or marine mammals, whether or not refined, but not chemically modified (US\$10 million).

The current bilateral trade relations do not reflect the real potential and there is a plenty of room to further enhance bilat eral trade relations. According to the World Bank, Chile is an upper-middle income economy and is one of South America's most stable and prosperous nations with a total GDP reaching US\$248.6 billion (2011) and a total population of 17.27 million (2011). Chile is a main exporter of coppers (producing over one-third of the global copper output), gold content, chemical wood pulp, fish products particularly salmon which is the second largest producer in the world, and wine. Meanwhile Indonesia is classified as a lower income economy and it is the largest economy in ASEAN with a total GDP reaching US $\$ 846.8$ billion (2011) and a total population of 242.3 million (2011) exporting main commodities among others coal briquettes, petroleum gases, crude palm oil, crude petroleum oils and natural rubber.

Based on the main export commodities, it is illustrated that both countries export different commodities to the world, thus implicitly reflect that both countries have different comparative advantages. The differences in the characteristics of the comparative advantages of both countries could also imply that there is a potential of trade complementarities between the two countries. Using the Trade Complementarity Index (TCI), during the period 19892012 although with some fluctuations but in general trend trade complementaries between both nations are steadily increasing in which in 1989 , TCI was only 22.24 points and in 2012 reaches 52.78 points. This means that the trade relations which used to be substitutes during the 1990s, and now particularly since early 2000 s bilateral trade relations are complementaries. The TCI results revealed that Indonesia and Chile have different structure of trade, meaning have different in factor endowment, and thus, different characteristics of comparative advantages.

TCI shows that there is plenty room in order to strengthen bilateral trade relations. Today, both countries attempt to further enhance a mutually beneficial bilateral economic relation through proposing the establishment of a bilateral Free Trade Agreement (FTA). The proposed RI-Chile bilateral FTA is a step forward to further strengthen Indonesia-Chile trade relations in the face of trade liberalization. A Joint Study Group on the Feasibility of a Free Trade Agreement between Indonesia and Chile has been concluded on 11-12 No- 
vember 2009 in Bali and the study found that a bilateral RI-Chile FTA would provide valuable benefits for both countries (DIRECON, 2009). Although for several years pre-negotiation talks stopped partly because Indonesia prioritized other trade talks, but however last April 2013, during the APEC forum trade ministers meeting in Surabaya, Indonesia and Chile signed terms of reference to prepare and begin talks on a Indonesia-Chile Comprehensive Economic Partnership Agreement (IC-CEPA) (Yulisman, 2013). With this IC-CEPA, Indonesia expects to create a free and fair bilateral trade agreement and also expects Chile to be a trade hub in South America. As a reference, Chile has signed agreements to liberalize trade with 58 nations and regions meanwhile for Indonesia, there are 20 initiatives to liberalize trade which are currently in the process of studies, negotiations or have entered into force (Sjahril, 2013).

Within bilateral relations, in an effort to strengthen economic and trade relations, both countries signed several agreements in the fields of trade and economic such as the Memorandum of Understanding on Economic and Trade Cooperation between Indonesia and Chile in 1987, Trade Agreement between the Government of
Chile and the Government of the Republic of Indonesia in 1992, the cooperation agreement between the Indonesian Chamber of Commerce and the Sociedad de Fomento Fabril in 1994, Memorandum of Understanding between the Central Bank of Chile and Bank Indonesia in 1997, the Memorandum of Understanding between Indonesia and Chile on the Establishment of Bilateral Consultations in 2002, the Memorandum of Understanding between PT. Argarindo Bogatama Who Represents the Indonesian Party and Algamas Marinas SA, Algamar Who Represents the Chilean Party in 2003, the Agreement between the Government of the Republic of Indonesia and the Government of the Republica of Chile on Economic and Technical Cooperation in 2004, and the Memorandum of Understanding between Indonesia and Chile on the Establishment of a Joint Commission on Economic and Technical Cooperation in 2008. The seriousness to further intensify particularly the bilateral economic cooperation can also be seen where Indonesia as the host last year organized "ASEAN Latin Business Forum 2012" on 9-10 July 2012 in Jakarta. The forum is arguably to be the largest Latin Business Forum in Indonesia and the region.

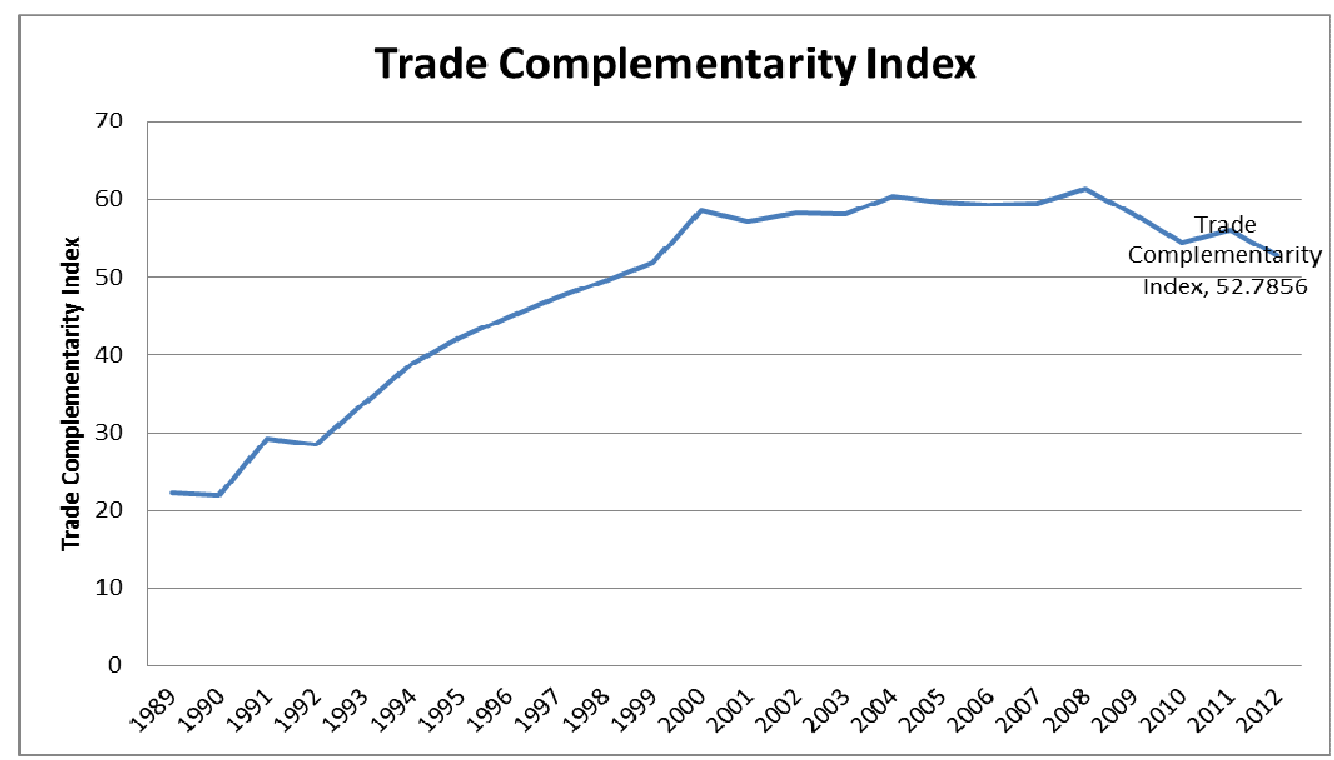

Figure 1. Trade Complementarity Index between Indonesia and Chile for the Period 1989-2012 
Within the regional and multilateral economic and socio-cultural foras, both countries are members of Asia Pacific Economic Cooperation (APEC), World Trade Organization (WTO), ASEANMERCOSUR and Forum for East Asian and Latin American Countries (FEALAC). In 2013, Indonesia hosts APEC Forum, WTO Ministerial Meetings and FEALAC Ministerial Meetings. During the sidelines of the APEC Forum, Indonesia and Chile signed terms of reference to prepare and begin talks on a IC-CEPA. Within the Sixth FEALAC Ministerial Meetings held last June 2013 in Bali, both countries have proactively make contributions in order to promote cooperation between both regions. FEALAC was established in 1999 andis an informal forum to link East Asian and Latin American countries and aims to promote cooperation, better understanding and political and economic dialogue between the regions in order to achieve more effective, cooperative and fruitful relations in all a $\mathrm{r}$ eas (Saragih, 2013).

Although many fruitful efforts have been made by both sides to enhance biltr- eral trade relations, but there are some alarming points need to be noted. Based on the Trade Intensity Index (TII), the paper found that during the period 1995-1999, the average TII reached 0.6 points and since then, TII decreased over the years and in 2012 reached to one of the lowest level since 1992 at 0.22 points. The TII shows whether the value of bilateral trade is greater or smaller than would be expected on the basis of their importance in world trade (World Integrated Trade Solutions, 2013). TII is less than one point which indicates that during the period 1989-2012 the bilateral trade flow is smaller than expected, given the partner country's importance in world trade. This means that Indonesian trade relations with Chile is not intense compared with its trading pattern with the rest of the world. This could also imply that both countries are still lacking interests and priorities in order to further boost bilateral trade cooperation and other classical issues such as the geographic long distance which causes high transportation costs; language barriers; the lack of information and people to people contacts.

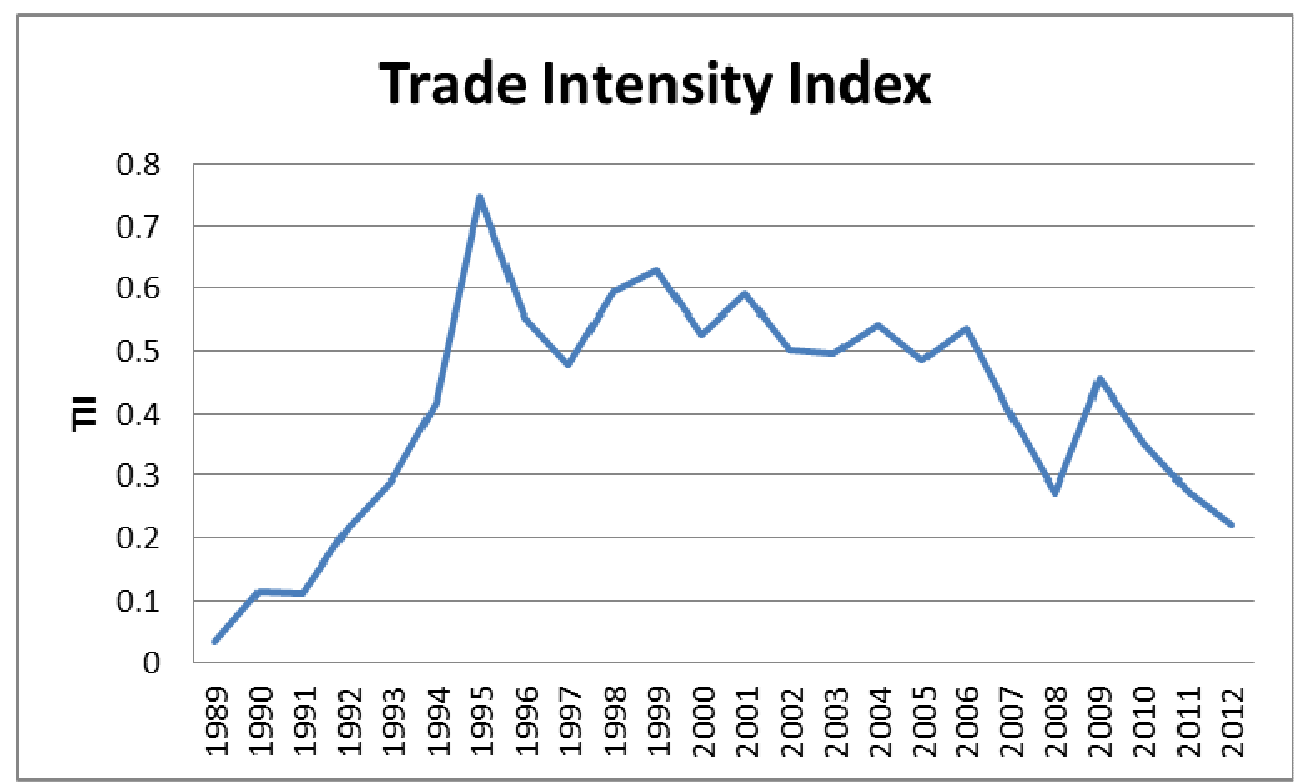

Figure 2: Trade Intensity Index between Indonesia and Chile for the Period 1989-2012 
Many of the current bilateral economic cooperation initiatives are tend to be as the result of the Chilean sides which aggressively attempt to enhance its economic diplomacy with Indonesia. In the millenium era, the Chilean government adopted a look east policy, meaning the pacific region has received much attention over the last few years. The main objectives are to push the Chilean economy with the current global economic downturn through finding and developing new markets particularly with its counterparts in the pacific region. Meanwhile Indonesian economic diplomacy towards Latin American and Caribbean regions is considered as an alternative market and this maybe imply that this region may not be as important compared with the Indonesian counterparts in the traditional markets. Thus, the efforts made by the Indonesian side with the alternative markets countries may not be as intense compared with its counterparts within the traditional markets.

Last but not least, it is also found that in 2011 Indonesian bilateral trade with its partners in the Latin American and Caribbean region only represents 1.47 percent of the total Indonesian trade. The highest was Brazil with 0.85 percent, followed by Argentina (0.17 percent), and Chile (0.1 percent). The trade was relatively constant over the years and showed little improvement. The region trade share reaches its peak only to 1.57 percent in 2010. In 2012, Indonesia's largest trading partner is Brazil (US\$3.35 billion) followed by Argentina (US\$2.06 billion) and Chile (US\$232 million). The current trade volumeac cording to many views does not reflect the potential trade volume a deeper economic relation could further be made in the future.

Few researches have been done so far particularly on issues concerning Indonesian economic diplomacy with the Latin American and Caribbean countries. However, some papers have investigated trade relations among those countries such as
Wignaraja et al. (2012) and BerishaKrasniqi et al. (2011). This paper attempts to identify and analyze the bilateral trade opportunities based on their respective export competitiveness (or comparative advantage).

Many studies related to export competitiveness analysis have been done by various researchers such as Benkovskis and Wörz (2013) on non-price competitiveness of export, Ahrend (2006) on industrual restructiring and competitiveness, or Benkovskis and Wörz (2012) on non-price competitiveness. However, very few researches have been made particularly in analyzing the Indonesian trade relations with its counterparts in the Latin American and Caribbean regions. Therefore, this research paper attempts to raise and propose a study with a title of: Assessing IndonesiaChile Bilateral Trade Opportunities: A Revealed Comparative Advantage Approach.

This study is expected to contribute in enriching scientific international trade literatures, particularly in the field of Indonesian economic diplomacy towards Latin American and Caribbean regions. For the policymakers, the research could be used as a reference for both Indonesian and Chilean governments to undertake the appropriate economic diplomacy measures in order to further enhance trade relations of both countries.

\section{METHODS}

The paper seeks to identify and analyze each country's export competitiveness. To analyze the export competitiveness, the indicator of so-called a Revealed Comparative Advantage (RCA) index will be used in this study. RCA index is one of the "export cum indices" category and first introduced by Balassa in 1965. RCA Index shows how competitive a product in countries' export is compared to the products share in world trade meaning a comparative advantage is "revealed" by observed trade patterns. A product with high RCA is com- 
petitive and can be exported to countries with low RCA. Countries with similar RCA profiles are unlikely to have strong bilateral trade intensities unless intra-industry trade is involved( Chandran, 2010). General international trade theory states that gain from trade come from specialization in a country's area of comparative advantage, for instance, products or sectors in which a country produces relatively more effciently or lower opportunity cost (Plummer et al, 2010). And by trading based on country's comparative advantage, it is predicted that it will benefit all trading partners and ultimately through specialization, it will result in a higher world output.

The computation of the RCA index is based on the publication released by Mikic and Gilbert (2009) titled: Trade Statistics in Policymaking: A Handbook of Commonly Used Trade Indices and Indicators and World Integrated Trade Solutions (WITS). The RCA index of country ' $i$ ' for product ' $j$ ' is often measured by the product's share in the country's exports in relation to its share in world trade:

$$
R C A_{i j}=\frac{X_{i j} / X_{i t}}{X_{w j} / X_{w t}}
$$

where $x_{i j}$ and $x_{w j}$ are the values of country $i$ 's exports of product $\mathrm{j}$ and world exports of product $\mathrm{j}$ and where $X_{i t}$ and $X_{w t}$ refer to the country's total exports and world total exports. A value of less than unity implies that the country has a revealed comparative disadvantage in the product. Similarly, if the index exceeds unity, the country is said to have a revealed comparative advantage in the product. The present study will use the HS 4 Digits Code (commodity-level) based on the trade data in year 2012 to analyze the Revealed Comparative Advantage Index (RCA Index) of both countries and only the top ten commodities with the highest RCA index in both countries will be discussed in this paper.

\section{RESULTS}

To analyze the export competitiveness of both countries, a Revealed Comparative Advantage (RCA) Index has been used to support this study. Using the HS 4 Digits and trade data 2012 (commodity-level), Indonesia has a strong comparative advantage among others are lignite, whether or not agglomerated, excluding jet (HS2702); coconut (copra), palm kernel or babassu oil and fractions thereof, whether or not refined, but not chemically modified (HS1513); palm oil and its fractions, whether or not refined, but not chemically modified (HS1511); copra (HS1203); and nickel ores and concentrates (HS2604). But however, out of the top ten Indonesian products with strongest export competitiveness, only 3 Indonesian commodities that are imported by Chile: natural rubber, balata, gutta percha, guayule, chicle and similar natural gums, in primary forms or in plates, sheets or strip (US\$5.12 million); yarn (other than sewing thread) of artificial staple fibres, not put up for retail sale (US\$183529); and palm oil and its fractions, whether or not refined, but not chemically modified (US\$300). The current top-ten Indonesian strongest export competitiveness only represents 3 percent of the total Indonesian exports to Chile.

Within the top ten Indonesian products exported to Chile, there are eight Indonesian export commodities with the RCA index greater than one indicating that Indonesia holds a comparative advantage in these commodities in the world market. But only one of the top ten Indonesian strongest export competitiveness enter the top ten Indonesian exports to Chile in 2012. Meanwhile comparing Indonesian RCA index vis a vis Chile, it is found that with the exceptions for the products Machinery for sorting, screening, separating, washing, crushing, grinding, mixing or kneading earth, stone, ores or other mineral substances, in solid (including powder or paste) form; machinery for agglomerating, 
shaping or moulding solid mineral fuels (HS8474) and Locust beans, seaweeds and other algae, sugar beet and sugar cane, fresh, chilled, frozen or dried, whether or not ground; fruit stones and kernels and other vegetable products (including unroasted chicory roots of the variety Cichorium intybus sativum) (HS1212), all the other top-ten Indonesian commodities exported to Chile have a better comparative advantage than the local Chilean products. Although the trend shows that in general Indonesian exports to Chile are based on its comparative advantage, but however the current exports still do not reflect its potential as most of the top ten Indonesian commodities with the strongest comparative advantage still do not able to penetrate the Chilean market. Thus, here there is a room to enhance bilateral trade relations particularly concerning with boosting trade relations based on their comparative advantage.

Meanwhile for the Chilean side, at the commodity-level the top ten Chilean strongest export competitiveness in 2012 among others are the unrefined copper; copper anodes for electrolytic refining ( $\mathrm{RCA}=116.66)$; fluorine, chlorine, bromine and iodine ( $\mathrm{RCA}=104.83)$; copper ores and concentrates $(\mathrm{RCA}=80.39)$; nitrites; nitrates $(\mathrm{RCA}=77.49)$; and refined copper and copper alloys, unwrought (RCA =71.79). Among the top-ten products, the biggest Chilean exports to Indonesia are the refined copper and copper alloys, unwrought amounted US\$72 million, followed by grapes, fresh or dried (US\$20.5 million), fluorine, chlorine, bromine and iodine (US\$0.37 million), and nitrites; nitrates (US\$0.34 million), thus, in total reaches US\$91.21 million and represents 44 percent of the total Chilean export to Indonesia. Based on the classical theory of comparative advantage by David Ricardo (1817) stated that a country with a comparative advantage in the production of a good should export and vice versa in order to boost world output. Higher world output reflects higher world welfare. Chile implicitly has demonstrated that to a certain degree, the current Chilean export to Indonesia already based on its comparative advantage.

Table 2: Top-Ten Indonesian Strongest Export Competitiveness for the Year 2012 (Commodity-Based)

\begin{tabular}{|c|c|c|c|}
\hline $\begin{array}{l}\text { HS } 4 \text { Dig- } \\
\text { its } \\
\text { Product } \\
\text { Code }\end{array}$ & Product Name & $\begin{array}{c}\text { IDN-CHL } \\
\text { Trade Value } \\
\text { in Millions } \\
\text { USD } \\
\end{array}$ & $\begin{array}{l}\text { RCA } \\
\text { Index }\end{array}$ \\
\hline 2702 & Lignite, whether or not agglomerated, exclude jet & 0.00 & 60.75 \\
\hline 1513 & $\begin{array}{l}\text { Coconut (copra), palm kernel or babassu oil and fractions } \\
\text { thereof, whether or not refined, but not chemically modified }\end{array}$ & 0.00 & 46.10 \\
\hline 1511 & $\begin{array}{l}\text { Palm oil and its fractions, whether or not refined, but not } \\
\text { chemically modified }\end{array}$ & US\$300 & 38.61 \\
\hline 1203 & Copra & 0.00 & 36.67 \\
\hline 2604 & Nickel ores and concentrates & 0.00 & 35.71 \\
\hline 2606 & Aluminium ores and concentrates & 0.00 & 34.22 \\
\hline 8001 & Unwrought tin & 0.00 & 30.88 \\
\hline 0410 & $\begin{array}{l}\text { Edible products of animal origin, not elsewhere specified or } \\
\text { included }\end{array}$ & 0.00 & 30.87 \\
\hline 4001 & $\begin{array}{l}\text { Natural rubber, balata, gutta-percha, guayule, chicle and } \\
\text { similar natural gums, in primary formsor in plates, sheets or } \\
\text { strip }\end{array}$ & 5.12 & 28.87 \\
\hline 5510 & $\begin{array}{l}\text { Yarn (other than sewing thread) of artificial staple fibres, } \\
\text { not put up for retail sale }\end{array}$ & 0.18 & 20.47 \\
\hline
\end{tabular}


Table 3: Top-Ten Indonesian Exports to Chile for the Year 2012: RCA Index (Commodity-Based)

\begin{tabular}{|c|c|c|c|}
\hline $\begin{array}{l}\text { HS } 4 \text { Dig- } \\
\text { its Product } \\
\text { Code }\end{array}$ & Product Name & $\begin{array}{l}\text { RCA Index } \\
\quad(\text { CHL })\end{array}$ & $\begin{array}{l}\text { RCA Index } \\
\text { (IDN) }\end{array}$ \\
\hline 6403 & $\begin{array}{l}\text { Footwear with outer soles of rubber, plastics, leather or } \\
\text { composition leather and uppers of leather }\end{array}$ & 0.08 & 4.72 \\
\hline 8418 & $\begin{array}{l}\text { Refrigerators, freezers and other refrigerating or free- } \\
\text { ing equipment, electric or other }\end{array}$ & 0.47 & 1.04 \\
\hline 2701 & $\begin{array}{l}\text { Coal, briquettes, avoids and similar solid fuels manu- } \\
\text { factured from coal }\end{array}$ & 0.00 & 16.59 \\
\hline 6402 & $\begin{array}{l}\text { Other footwear with outer soles and uppers of rubber or } \\
\text { plastics }\end{array}$ & 0.18 & 1.67 \\
\hline 6404 & $\begin{array}{l}\text { Footwear with outer soles of rubber, plastics, leather or } \\
\text { composition leather and uppers of textilemater ials }\end{array}$ & 0.92 & 3.65 \\
\hline 8474 & $\begin{array}{l}\text { Machinery for sorting, screening, separating, washing, } \\
\text { crushing, grinding, mixing or kneading earth, stone, } \\
\text { ores or other mineral substances, in solid (including } \\
\text { powder or paste) form; machinery for agglomerating, } \\
\text { shaping or moulding solid mineral fuels }\end{array}$ & 0.88 & 0.46 \\
\hline 8703 & $\begin{array}{l}\text { Motor cars and other motor vehicles principally designed } \\
\text { for the transport of persons (other than those of heading } \\
87.02 \text { ), including station wagons and racing cars. }\end{array}$ & 0.13 & 0.29 \\
\hline 1212 & $\begin{array}{l}\text { Locust beans, seaweeds and other algae, sugar beet and } \\
\text { sugar cane, fresh, chilled, frozen or dried, whether or } \\
\text { not ground; fruit stones and kernels and other vegetable } \\
\text { products (including unroasted chicory roots of the vari- } \\
\text { ety Cichorium intybus sativum) }\end{array}$ & 14.33 & 8.46 \\
\hline 4001 & $\begin{array}{l}\text { Natural rubber, balata, gutta-percha, guayule, chicle } \\
\text { and similar natural gums, in primary forms or in plates, } \\
\text { sheets or strip }\end{array}$ & 0.01 & 28.87 \\
\hline 8507 & $\begin{array}{l}\text { Electric accumulators, including separators therefor, } \\
\text { whether or not rectangular (including square) }\end{array}$ & 0.01 & 1.05 \\
\hline
\end{tabular}

Table4: Top-Ten Chilean Strongest Export Competitiveness for the Year 2012: RCA Index (Commodity-Based)

\begin{tabular}{|c|c|c|c|}
\hline $\begin{array}{c}\text { HS } 4 \text { Digits } \\
\text { Product Code }\end{array}$ & Product Name & $\begin{array}{c}\text { CHŁ IDN } \\
\text { Export Value } \\
\text { in Million USD }\end{array}$ & $\begin{array}{l}\text { RCA } \\
\text { Index }\end{array}$ \\
\hline 7402 & $\begin{array}{l}\text { Unrefined copper; copper anodes for electrolytic } \\
\text { refining }\end{array}$ & 0.00 & 116.66 \\
\hline 2801 & Fluorine, chlorine, bromine and iodine & 0.37 & 104.83 \\
\hline 2603 & Copper ores and concentrates & 0.00 & 80.39 \\
\hline 2834 & Nitrites; nitrates & 0.34 & 77.49 \\
\hline 7403 & Refined copper and copper alloys, unwrought & 72.00 & 71.79 \\
\hline 7401 & Copper mattes; cement copper (precipitated copper) & 0.00 & 68.75 \\
\hline 2613 & Molybdenum ores and concentrates & 0.00 & 61.73 \\
\hline 2702 & $\begin{array}{l}\text { Lignite, whether or not agglomerated, excluding jet } \\
\text { Coconut (copra), palm kernel or babassu oil and }\end{array}$ & 0.00 & 60.75 \\
\hline 1513 & $\begin{array}{l}\text { fractions thereof, whether or not refined, but not } \\
\text { chemically modified. }\end{array}$ & 0.00 & 46.10 \\
\hline 0806 & Grapes, fresh or dried & 20.50 & 43.50 \\
\hline
\end{tabular}


Table 5: Top-Ten Indonesian Imports from Chile for the Year 2012: RCA Index (Commodity-Based)

\begin{tabular}{|c|c|c|c|}
\hline $\begin{array}{l}\text { HS } 4 \text { Digits } \\
\text { Product Code }\end{array}$ & Product Name & $\begin{array}{l}\text { RCA Index } \\
\quad(\mathrm{CHL})\end{array}$ & $\begin{array}{l}\text { RCA Index } \\
\text { (IDN) }\end{array}$ \\
\hline 7403 & Refined copper and copper alloys, unwrought & 71.79 & 1.21 \\
\hline 2601 & $\begin{array}{l}\text { Iron ores and concentrates, including roasted iron } \\
\text { pyrites }\end{array}$ & 2.25 & 0.17 \\
\hline 4703 & $\begin{array}{l}\text { Chemical wood pulp, soda or sulphate, other than } \\
\text { dissolving grades }\end{array}$ & 18.78 & 4.72 \\
\hline 0806 & Grapes, fresh or dried & 43.50 & 0.00 \\
\hline 1504 & $\begin{array}{l}\text { Fats and oils and their fractions, of fishor marine } \\
\text { mammals, whether or not refined, but not chemi- } \\
\text { cally modified }\end{array}$ & 24.19 & 0.09 \\
\hline 2301 & $\begin{array}{l}\text { Flours, meals and pellets, of meat or meat offal, of } \\
\text { fishor of crustaceans, molluscs or other aquatic } \\
\text { invertebrates, unfit for human consumption; } \\
\text { greaves }\end{array}$ & 27.70 & 0.11 \\
\hline 7204 & $\begin{array}{l}\text { Ferrous waste and scrap; remelting scrap ingots of } \\
\text { iron or steel }\end{array}$ & 0.40 & 0.11 \\
\hline 3104 & Mineral or chemical fertilisers, potassic & 7.53 & 0.07 \\
\hline 4706 & $\begin{array}{l}\text { Pulps of fibres derived from recovered (waste and } \\
\text { scrap) paper or paperboard or of other fibrous cel- } \\
\text { lulosic material }\end{array}$ & 0.02 & 0.04 \\
\hline 3102 & Mineral or chemical fertilisers, nitrogenous. & 2.29 & 1.67 \\
\hline
\end{tabular}

At the commodity level there are two out of the top-ten Chilean strongest export competitiveness that entered into the top-ten Indonesian imports from Chile. But however, it was mainly dominated by the refined copper and copper alloys, unwrought amounted US\$72 million accounted for 34.85 percent of the total Indonesian imports from Chile) followed by grapes, fresh or dried amounted US\$20.5 million (10 percent) and the rest of the commodities were very small where combined only reached US\$0.71 million. The majority of the top-ten Chilean exports to Indonesia are based on its comparative advantage and two of them are within the top-ten Chilean strongest export competitiveness commodities. Thus, there is still plenty room to further enhance Chilean exports to Indonesia based on its comparative advantage.

\section{CONCLUSION}

The present study reveals that there are still opportunities for both countries to further intensify bilateral trade cooperation. Using the Trade Complementarity Index (TCI), although with certain fluctuations the bilaeral trade relations which used to be substitutes during the 1990s, now particularly since early 2000 s bilateral trade relations are more complementaries and this implies that Indonesia and Chile have different structure of trade and thus, different characteristics of comparative advantages. Although many fruitful efforts have been made by both sides to enhance bilateral trade relations through bilateral, regional and multilateral foras, but there are still alarming points need to be noted. Based on the Trade Intensity Index (TII), the paper found that particularly since 2000s TII has decreased over the years. This means that Indonesian trade relations with Chile is not intense compared with its trading pattern with the rest of the world. This could also maybe imply that both countries are still lacking interests and priorities in order to further boost bilateral trade cooperations and other classical issues such as the geo- 
graphic long distance which causes high transportation costs; language barriers; the lack of information and people to people contacts.

Based on the RCA Index analysis, the study finds that the current top-ten Indonesian strongest export competitiveness only represents 3 percent of the total Indonesian exports to Chile. Within the top ten Indonesian products exported to Chile, there are eight Indonesian export commodities with comparative advantages, but only one of the top ten Indonesian with the strongest export competitiveness enter the top ten Indonesian exports to Chile in 2012. Meanwhile on the other hand, the majority of the top-ten Chilean exports to Indonesia are based on its comparative advantage and two of them are within the top-ten Chilean strongest export competitiveness commodities. But however, it was mainly dominated by the refined copper and copper alloys, unwrought followed by grapes, fresh or dried. Thus, the analysis found that there is still plenty of room for both sides to further enhance their exports based on their respective comparative advantages.
In 2013, both nations agreed and signed terms of reference to prepare and begin talks on a Indonesia-Chile Comprehensive Economic Partnership Agreement (IC-CEPA). With this IC-CEPA, both countries expect to create among others a free and fair bilateral trade agreement. The paper suggests within the IC-CEPA negotiation in the near future, both countries should remove trade barriers starting from providing access for the top 10 commodities with the strongest comparative advantage to penetrate in both countries. Few of the top ten export commodities with strongest competitiveness are represented within the current bilateral trade relations, thus, by removing trade barriers starting from providing access for the top $10 \mathrm{com}$ modities with the strongest comparative advantage could be one major starting step to start a bilateral free trade. By eliminating trade barriers, both countries will reap higher welfare and also fulfilling the objectives of both countries to further intensify bilateral trade relations.

\section{REFERENCES}

Ahrend, R. (2006) "Russian Industrial Restructuring: Trends in Productivity, Competitiveness and Comparative Advantage," Post-Communist Economies, 18(3), 277-295.

Aisen A., R. Álvarez, A. Sagner, and J. Turén (2011), "Credit Contraction and International Trade: Evidence from Chilean Exprters," Banco Central de Chile Documentos de Trabajo, Central Bank of Chile Working Papers No. 639.

Alvarez, R. and R. Fuentes (2003), "Trade Reforms and manufacturing Indstry in Chile," Banco Central de Chile, Documentos de Trabajo, Central Bank of Chile Working Papers No. 210.

Benkovskis, K. and J. Wörz (2012), "Non-Price Competitiveness Gains of Central, Eastern and Southeastern European Countries in the EU Market," Focus on European Economic Integration, 3, 27-47.

Benkovskis, K. and J. Wörz (2013), "Non-Price Competitiveness of Exports from Emerging Countries," European Central Bank, Working Paper Series No. 1612, November 2013.

Berisha-Krasniqi, V., A. Bouët, C. Estrades, and D. Laborde (2011), "Trade and Investment in Latin America and Asia Lessons from the Past and Potential Perspectives from Further Integration,” IFPRI Discussion Paper 01060, January 2011. 
Chandran, S., (2010), "Trade Complementarity and Similarity between India and ASEAN Countries in the Context of the RTA," MPRA Paper No. 29279.

Direcon (2009), "Chile-Indonesia Joint Study Group on the Feasibility of a Free Trade Agreement: Final Report," Ministry of Foreign Affairs for the Republic of Chile, 11-12 November.

Mikic, M. and J. Gilbert (2009), Trade Statistics in Policymaking: A Handbook of Commonly Used Trade Indices and Indicators, Revised Edition, United Nations ESCAP, Bangkok. Last Retrieved 5 September 2012.

Plummer, M.G., D. Cheong, and S. Hamanaka (2010), Methodology for Impact Assessment of Free Trade Agreements, Mandaluyong City, Asian Development Bank.

Ricardo, D. (1817), "On the Principles of Political Economy and Taxation," Available in: the International Economics Study Center. Last Retrieved 4 July 2013: http://www.freerepublic.com/focus/f-news/1101717/posts.

Saragih, B. (2013), "6 ${ }^{\text {th }}$ FEALAC Meeting Set to Kick Off in Bali," Jakarta Post Online, Jakarta, 13 June. Last Retrieved 2 July 2013: http://www.thejakartapost.com/news/2013/06/13/6th-fealac-meeting-set-kick$\underline{\text { bali.html }}$

Sjahril, S.S. (2013), "Assessing Potential and Impact on Bilateral Free Trade Scenario Between Indonesia and Chile," Proceedings International Research Conference on Business and Economics, Semarang, 28-30 June.

Wignaraja, G., D. Ramizo, and L. Burmeister (2012), "Latin America Free Trade Agreements: An Instrument for Inter-Regional Liberalization and Integration?" ADBI Working Paper Series No. 382, September 2012.

World Integrated Trade Solutions (2013), Trade Indicators, Last Retrieved 2 July 2013: http://wits.worldbank.org/WITS/WITS/WITSHELP/Content/Utilities/e1.trade_indi cators.htm

Yulisman, L. (2013), "Indonesia to Kick Off CEPA Talks with Chile," Jakarta Post Online, Jakarta, 22 April. Last Retrieved 2 July 2013: http://www.thejakartapost.com/news/2013/04/22/indonesia-kick-cepa-talks-withchile.html. 